\title{
LIVE METAPHORS OF MEANING ${ }^{1}$
}

\section{V.P. ZINCHENKO}

Reflections on meaning are as indestructible as nature itself: they give a chance to build a "freedom for...". L.S. Vygotsky wrote that, as Locke, Leibnitz and all linguistics had shown, all words of psychology are metaphors taken from spaces in the world. One can certainly argue as to whether all psychological words are metaphors, but there is no doubt that psychologists do not strictly define the word "meaning." Vygotsky also did not define it. A kind of excuse for the absence or inadequacy of the definition of "meaning" can be found in the works of A.N. Leontiev. D.A. Leontiev used his words as an epigraph to the first monograph in the Russian psychology called The Psychology of Meaning: "The problem of meaning is the last analytical concept crowning the general doctrine of psyche, as well as the concept of the personality crowns the whole system of psychology." The contents of the book show that the concept of meaning would have to be the first, and without it neither the general doctrine of psyche nor the system of psychology (if the term "system" is applicable to science in general) could be built. The point is not even as to whether the concept of the meaning is to be original or crowning, but whether meaning needs (does it indeed?) to be made into a concept, and there, God willing, it will be either an analytic or synthetic concept. This does not mean that in psychology and the humanities in general there is no concept of the meaning. On the contrary. Such notions are too numerous.

D.A. Leontiev, having analyzed many definitions (interpretations) of meaning, suggests that behind the concept (the word-concept, to be more precise) of "meaning" there is not a specific psychological structure, allowing an unambiguous definition, but a complex and multifaceted semantic reality (Leontiev, 1999, p. 105). As far as giving a definition to meaning is concerned we think that this is not an assumption, but a statement of the status quo. Defining a concept is quite a difficult (and unrewarding) task, and the definition of the concept of meaning causes unprecedented trouble. After all, in the triangle of G.Frege the very concept is the signification of

\footnotetext{
${ }^{1}$ Translated from: Zinchenko, V. P. (2012). Live metaphors of meaning. In T. G. Shchedrina (Ed.), Methodology of psychology: problems and prospects (pp. 29-50). Saint Petersburg: Tsentr gumanitarnykh initsiativ. Translated and published with a permission of the publishing house «Tsentr gumanitarnykh initsiativ». Poetry is translated by E. Gaevskaya и D. Vonsboro.
} 
meaning: accordingly, the meaning (the word) indicating meaning (denotation), is a meaning (concept).

To avoid the confusion of being lost between the proverbial three pines, we shall not go into the debate over concepts but will accept that meaning is not so much a notion as a concept of culture. Yu.S. Stepanov understands it as "a phenomenon akin to the notion, but differing from it with its content, form and the scope of existence: its scope is the mental world, not logic but culture in any of its aspects; its form is not a scientific term but a word and a word combination from general language; its content belongs to all of society..." (Stepanov, 2004, p. 9). We believe that L.S. Vygotsky was also far from the notion of "meaning" and even more so from the analytic concept of it. Affective-semantic formations were a cultural reality to him. His version of cultural-historical psychology is rather a way to understand the meaning of the mind and consciousness. We shall illustrate this position.

L.S. Vygotsky started his scientific activities with the psychology of art (the manuscript of the book of the same name dates from the year 1925). He saw its subject matter and the objective in the study of the aesthetic response, a form of which is catharsis. Such an interpretation of the subject of the psychology of art can be considered as a tribute to the time and can be explained by his early interest in the theory of conditioned reflexes of I.P. Pavlov and in reactology of K.N. Kornilov. In The Historical Meaning of the Psychological Crisis he confirms that the main subject of his research in the psychology of art is the aesthetic response. The importance of the problem is empha- sized here: "to find the borders and meaning of the aesthetic response in art" (Vygotsky, 1982a, pp. 405-406). At the end of the book The Psychology of Art L.S. Vygotsky came to the meaning, including "the second meaning" in The Tragedy of Hamlet: "Not to solve the riddle but to accept the mystery, to sense it, to feel it" (Vygotsky, 1996, p. 485). The author concludes that both the work of art and its perception are characterized by incompleteness and understatement: "artistic perception is a "startled," interrupted, incomplete perception; it inevitably leads to a different thing - to replenishing of the words of tragedy with silence" (Ibid., p. 491). In other words, to the work of experiencing and understanding.

Closest students of L.S. Vygotsky A.V. Zaporozhets and D.B. Elkonin appreciated Vygotsky's provisions on the objectivity of existence of affectivesemantic formations represented in works of art and other creations by humanity. It is clear in the light of these provisions why Vygotsky argued that experience was the unit of analysis of consciousness (it would be more accurately called the source of consciousness). In terms of modern characteristics of science that emphasize interdisciplinarity in constructing models used to synthesize investigations in different areas of knowledge, Vygotsky was a classic of modern science. However, his scientific work was devoid of the essence of the latter, i.e. its omnivorous, eclectic and amateurish nature. It is scary even to think of its zone of proximal development: the science that departs further and further from meaning.

The path to meaning is similarly traced in the book Thought and 
Speech. At the beginning of the book the author puts forward sense as a common unit of analysis for both processes (thought and speech). Sense is the main subject of the interesting studies throughout most of the book. In the course of the development of logic and results of the studies and in the course of writing the book (towards the end) this option ceased to conform to the author's intention so the focus (most likely without the author being aware of it) shifted from sense to meaning (Zinchenko V., 2006, p. 10). Perhaps he felt something similar to what R.M. Rilke expressed as follows: "... we feel little secure and at home in our interpreted world."

In the article The Problem of Mental Retardation that was being written, apparently, in parallel with the book mentioned, L.S. Vygotsky (while discussing the relationship between thought and action) considers them as two types of activities, each of which is a dynamic semantic system (Vygotsky, 1982c, pp. 250-251). As speech is a kind of activity too, there is no doubt that this characteristic also applies to it. These provisions are related to L.S. Vygotsky's idea (that was deployed sparingly) on the semantic structure of consciousness.

Thus, the concept of meaning is present in many constructions by L.S. Vygotsky; one might even say that it is central to his theory. And the notion of meaning, if implied, is too vague causing discrepancies in interpreting his works and a sense of understatement. We shall say once again that L.S. Vygotsky was not alone in this. Such a situation is typical not only to psychology, but also, we dare say, to the entirety of human knowledge.
Many verbal and, in a way, even logical definitions give the appearance of clarity to the mystery of meaning. This is what makes us turn to metaphors, or, sorry for the tautology, to meaningful images of meaning. Addressing metaphor removes the illusion of clarity; it shows the incompleteness, at times the banalality of definitions; it brings us back to the mystery of meaning and encourages the urge to touch it, to make it more noticeable. Metaphors and meaningful images help revitalize existing concepts or notions of meaning. The approach to a living notion (which is a kind of intelligible matter), is through a living metaphor. Eventually metaphor facilitates understanding, and the latter is indispensable in gaining knowledge that can be applicable for anything at all.

To understand something, it is necessary to go beyond it. In Greek the word "metaphor" literally means "a trolley." A trolley is used to transport goods from point A to point B. V.L. Rabinovich pointed out that in the case of metaphor the points (objects) A and B are located in different semantic spaces. Meaning is the cargo, which the metaphor "carries." Something A is endowed and enriched by the meaning of some other B. Hence, metaphor is a means of sharing, expanding and deepening of meaning. But the transfer of meaning does not violate the integrity of extreme elements that are linked by metaphor.

The significance of metaphor in science is indisputable, nevertheless we shall specifically cite some of the statements that represent general cultural interest and are intended not only for readers particularly concerned with the conceptual rigor of science. 
B.L. Pasternak: "Metaphors are shorthand for the great personality, a cursive script of its spirit. Our business is to understand metaphors and, if possible, to decipher them." Osip Mandelstam: "The earth hums with metaphor." Dante could say: "I compare, therefore I live." He was the Descartes of metaphor. For only through metaphor does the matter reveal itself to our consciousness (where can we get a different one?), for there is no existence beyond comparison, for existence itself is a comparison" (Mandelstam, 1987, p. 161). Metaphor is certainly greater than comparison. There is an element of inspiration in it too. It has a deep and rich inner form. G.G. Shpet talked about this form and its grounds: “... Metaphor, simile, personification, comparison of the familiar with the unfamiliar and vice versa, and so on, all this has its grounds and an ontological basis as well, but the subject of this ontology is the word" (Shpet, 1989, p. 447). S.S. Averintsev: "Whenever a philosophical term has already become a philosophical term, it is even more straightforward, deliberately fixed, and stable: otherwise it would not have been the term. So, both the common word and the term are subjects that hardly move, they "know their place" and do not allow movement from that place. But a shift is needed to give birth to a term. If to imagine that a common word as such may become a term, we have a kind of Zeno's arrow paradox: the arrow is here now in such a place, and a moment later it is in another place, but when and how did it manage to move? Between the common word and the philosophical term must certainly be an area in which words are released from a rigid connection with their "place" in life, are shifted from it, come out from their coasts, of equality with themselves. In other words, it is an area of metaphor. After all, the philosophical term, if we look at it from the opposite pole, from the sphere of everyday speech, is nothing other than a set, fixed, frozen metaphor: a common word regularly used in an improper sense" (Averintsev, 1979, pp. 51-52).

P. Ricoeur, who developed the theory of living metaphor, put metaphor on the border between psychology and semantics, and claimed that this border was where the logic and the sensory were connected, or the verbal and the non-verbal were linked. He considered metaphor to be a stream of images generated by meaning, as the deployment of meaning into images, including into verbal iconic signs. However, iconicity implies control over image on the part of meaning and the use of the "picturesque" potency of language. Ricoeur, referring to Wittgenstein, relates metaphor to the "to see how" phenomenon. To explain metaphor means to list those senses in which image is seen as meaning. "To see how" is an intuitive attitude that holds together meaning and image. "To see how" is action, because to understand means to do something (Ricoeur, 1990, pp. 435-455). More precisely, the metaphorical image contains in its internal form actions and word, along with their meanings that are in their inner form, i.e. as if in the inner form of the second order. P. Ricoeur concludes his analysis with the following: "Thus, 'to see how' performs exactly the role of a scheme, which unites an empty concept and a blind impression; being a half thought and a half feeling, this action-feeling links the clarity of thought and the fullness of 
image. Thus, the non-verbal and the verbal, too, are closely related to each other (in the framework of the figurative function of language)" (Ibid., p. 452). We should only note that "image, as well as concept, is not a reproduction and, therefore, "imagination" is neither "perception" nor "representation." It is between the representation and the concept. It should be comparable with the "admission" (according to Meinong's terminology)" (Shpet, 2007, pp. 265-266). "Assumption", or hypothesis, is "to see how." Shpet's explanation is very important: finding a living metaphor is a means of research, rather than a replacement.

As (according to Ricoeur) the metaphorical meaning is grown in the thickness of images, it is interesting to see what images are behind the very concept of meaning. Could this widely used concept be empty? What are the body, the flesh and the face of meaning (metaphors suggested by M.M. Bakhtin) in psychology? To what extent is its face expressive and intelligible? Is the body of meaning equivalent to the sounding and speaking flesh of the Russian language as Mandelstam wrote about? What is the style of the verbal robes of thought or what is the poetic costume of thought (Shpet's metaphor)? What is the style forming the methodological integrity of psychological concepts? To what extent does the idea meet intuition and taste, is it aesthetically pleasing?

First, we shall mention how broadly the concept of meaning was used beyond L.S.Vygotsky's theory. A.A. Ukhtomsky included meaning into the definition of life: life demands meaning and beauty within existence. Behaviour and activity have a meaning too. It is interesting that being a physiologist and biomechanic N.A. Bernstein took the concept of "meaning" as a key one when creating his theory of constructing movement. Meaning soars above objectives: motor, perceptual, mnemic, intellectual, etc. Apparently, this is why his theory was more widely dissiminated among psychologists than among physiologists. Especially since he (unlike the latter) never avoided the concept of "image".

Alongside with biological or vital meaning, there is also personal meaning (A.N. Leontiev). There is the transpersonal, or suprapersonal, meaning (Jung). Meaning acts in overt and covert forms. A.N. Leontiev once described meaning as the major unit of the analysis of the psyche and was going to prove it, but later gave up the idea after he had identified meaning as one of the elements forming consciousness (along with sense and sensual tissue).

F.E. Vasilyuk, when analyzing the overcoming of critical situations (loss of meaning, a life crisis), concluded that it is possible to gain a new meaning in life in the activities of experience (see Vasilyuk, 1984) (the work of grief as Freud put it). This is quite plausible, especially considering that experience (according to Vygotsky) is the unit of analysis of consciousness and a consciousness forming element (apparently forgotten by A.N. Leontiev). The work of understanding is also close to the experience. Understanding in external and internal dialogues is provided by two oppositely directed processes: the process of giving sense to meaning and the process of interpreting the senses (Zinchenko V., 2002). The Möbius strip is suitable to illus- 
trate the relationship between senses and meanings. In the process of either understanding or thinking the specified processes-actions flow into each other. On the outer side of the strip there may be a sense that is transformed into a meaning as a result of interpretation and this then becomes the internal side of the same strip. A similar result occurs when the meaning is given a value: a newly interpreted meaning is transferred to the outside of the Мцbius strip.

In an effort to define a concept (or to describe a phenomenon), its "meaning" is correlated with values, symbols, spirit (it is sometimes identified with them), as well as with needs, motivations, goals, values, attitudes, points of view, orientations, and focus of the individual. Objectified meaning, along with the sign, word, symbol, and face, is regarded as a carrier of the ideal form, a means (mediator) of development and personal growth (Zinchenko V., 1997).

Philosophers consider meaning as "the outer essence of a phenomenon that justifies its existence through associating it with a wider stratum of reality. By determining the location of the phenomenon in a certain integrity, meaning transforms its implementation into a need corresponding to the ontological order of things" (Shreider, 2000, p. 576). Of course, in such a general way this universal category can be applied to socio-cultural determinants of cognition in the analysis of scientific and cognitive activity, in other words, it can also act as an approach to interpreting the scientific and cognitive activity and, in fact, it really is the activity itself. The meaning of knowledge, from this point of view, is given by external socio-cultural goals and external socio-cultural "order of things." And it is exhausted by those. However, then there can be no discussion of grounds of the integrity of knowledge, of the true meaning of knowledge as such. Even if they are not denied, there is nothing to say about them. The appeal to the inherent semantic characteristics of knowledge becomes focused on its immanent forms of expression. And this appeal directs this focus onto taking into account the socio-cultural contexts of knowledge only through the prism of language as a means of communication in the culture of the scientific community and, above all, through its sign nature. Knowledge here is seen as a social and cultural phenomenon as knowledge of the world expressed in language, that is of something that is neither society nor culture. Language sets in its stylistic features the semantic specifics of knowledge as such, as a particular social and cultural phenomenon, above all, as a sign of the world. A "sign not only points to something, but it also expresses something about that something. This statement is the meaning of the sign, which introduces the indicated object or circumstances into the general order of things and events. Thus, the indication of something by this sign is transormed from the occasional into the necessary as arising from the meaning of this sign. This meaning is beyond the sign situation. It connects the act of indication with the system of linguistic meanings and makes this act semantically eligible" (Ibid.).

From this brief and incomplete list it follows that meaning pervades and permeates all areas of psychology, and 
we psychologists can if not say (after Acmeists the poets): We are smysloviki ${ }^{1}$, but acknowledge that we are longing for meaning. We would like in the least to be ironic about it. On the contrary, having a bird's-eye view of the history of psychology, it is good to know that it is gradually moving from such major words as "association", "Gestalt", "set", "operation”, "behaviour", "activity" to the word "meaning".

A.N. Leontiev once gave an operational definition, or rather a characteristic of meaning as the relationship of the motif to the target. One of the first attempts to measure this relationship was made by P.I. Zinchenko (1961). In the 1940s while studying memory he varied the force of motif and the richness of content, or the meaningfulness of mnemonic tasks. The results were quite significant: a strong motivation and a meaningless task provide the same low memory performance as a poor motivation combined with a meaningful task. There are tests that measure purpose-in-life orientations (D.A. Leontiev). But this is hardly anything compared with the demonstrated breadth of using the cultural concept of "meaning". We shall address options of metaphoric concretization of this concept and some psychological phenomena associated with them.

$* * *$

The metaphor of the abyss of meaning. This not too optimistic metaphor belongs to E. Husserl. "Between the meanings of consciousness and reality yawns a veritable abyss" (1952). Al- though the metaphor is almost 100 years old, we can not say that this gap has been overcome or filled. It may not still be as hopeless, especially if we believe Osip Mandelstam:

It is the prophet's sight that with soles Has trodden a path in the void.

Scientists too have managed to tread such paths. Psychologists are only gradually managing to fill the semantic abysses between stimuli and responses, knowledge and action, affect and intellect, education and development, consciousness and activities. Success in this area is determined by how far they move away from the mechanistically and statistically interpreted determinism and how closely they approach the understanding of the phenomenon (the concept) of freedom. Freedom that obeys internal or its own meanings and impulses. Compared to the abyss of meaning the image of the world of human meanings sounds more optimistic, which, like any other world, is inexhaustible. A "light" version of the metaphor of the abyss is a well-known semantic barrier that arises in solving a problem, in communication between people, etc.

The metaphor of the semiosphere belongs to Yu.M. Lotman. He differentiated the semiosphere from the noosphere of V.I. Vernadsky, which has material-spatial existence. The semiosphere, (although it has a sign or a sign communicative act as its primary element), is - according to Lotman - abstract. He understood the semiosphere

\footnotetext{
${ }^{1}$ From the Russian word "smysl” ("meaning”).
} 
as not only a set of signs or texts (seen as building bricks), but as "the semiotic space, outside of which semiosis cannot exist" (Lotman, 2005). The semiosphere is structurally homogeneous, it has its limits that are the areas of enhanced formation of meaning. Structural nuclei on the periphery of the semiosphere can move to its center, and the ones that were in the center can relocate to the periphery. "The internal diversity of the semiosphere implies its integrity. Parts enter the whole not as mechanistic details, but as organs in organisms" (Ibid.). Further we will again come across reflections on the organic existence of meaning. It is also important that connections between the parts of the semiosphere are complex and characterized by a high degree of de-automatization, hence, are unpredictable. Finally, Lotman's conclusion: dialogue is the basis of all meaningmaking processes.

The history of education and science has been accompanied by the search for methods of compressing meaning, of designing schemas, of "abbreviating knowledge” (Hegel). The semiosphere is one of the possible images of such compression, reminiscent of globus intellectualis by Leibniz. L.S. Vygotsky too had his own version of "semantic globe". The geographical metaphor helped him understand the mutual semantic methodological dependence of concepts. The longitude of concept was used to denote the space occupied by the latter between the poles of a very specific thought and of a highly abstract thought on the subject. The latitude was the place occupied by the concept among other concepts of the same longitude, but relating to other points of reality. Longitude and latitude of the concept together give an idea of the concept from the standpoint of an act of thought contained in it and an object presented in them (Vygotsky, 1982b, p. 274). The location (node) of the concept defined by its longitude and latitude, characterizes both the measure of generality of the concept and its meaning.

We shall note that the considered spatial metaphors of meaning (the abyss, the barrier, the world, the semiosphere) provide its objective existence. Despite the temptation, we would be in no hurry to identify spatial and "network" metaphors (that are considered further) with the Internet. These images of meaning are true for all times and perfectly emphasize the mystery of meaning and should serve as a starting point for those who dare touch it. From spatial metaphors we shall move to forms of the existence of meaning.

The metaphor of the web of meanings belongs to Max Weber: "man is an animal suspended in webs of significance he himself has spun" (spun out of his own existence, we should add, and this complies with the statement of G. Shpet on meaning being rooted in the existence). Meaning is so rooted in the existence that (from the point of view of M.M. Bakhtin) it even generates it and moves forward life and existence. This is not a contradiction between the views of G.G. Shpet and M.M. Bakhtin. It is only appropriate to discuss existence and meaning (consciousness) not as two separate things (entities) but as a single continuum (M.K. Mamardashvili). The same applies to a favourite issue of psychologists: the relationship of consciousness and activity. In fact, consciousness is full of activity, and 
activity has meaning, is concentrated on and is conscious. Another question is to what extent and how they interpenetrate into each other. Is the unity of consciousness and activity, long dreamt of by psychologists, possible? It is important that their isolated existence is impossible. Both S.L. Rubinstein and A.N. Leontiev understood that.

But we shall get back to the metaphor of Weber. If to read it literally, the question arises: how does the meaning represented as a spider's web move anything? After all, the web itself, likewise the meaning, fluctuates, trembles and vibrates. What do these vibrations resonate with? We shall recall that N.A. Bernstein to describe the living movement and, of course, regardless of Max Weber, used the same metaphor of the web (in the wind). This metaphor is also reminiscent of a "hovering action" by Novalis. The research by N.A. Bernstein showed that each movement is unique as a fingerprint; the exercise is a repetition without repetition; the movement is not repeated but each time is constructed. The dispersion between movements of the same type cannot be eliminated, and when they are superimposed on each other, they really look like a spider web. So, one and the same purpose is achieved in different ways (paths) and all of them can be equally effective. But the prerequisite for effectiveness is (according to N.A. Bernstein) the presence of the meaning of the motor task. The physiologist and biomechanic postulated the need for meaning, without specifying "what it looks like."

Images (kinesthetic and visual) that regulate the implementation of movements and actions can also be repre- sented as a web in the wind. The visual image in a way hovers, soars, breathes, changes and vibrates. Its formation, no less than the construction of movements, is subordinate to the meaning of the perceptual task. With the experience in solving motor tasks accumulating the space becomes functional, the motor, or action, field is formed. When the experience in solving perceptual tasks accumulates, the optical space becomes phenomenal, or semantic. In the words of W. Koehler, the person ceases to be a slave of the visual field and goes beyond it. This is possible due to the free intention (K. Lewin), that is thought, plan, and, perhaps, intent.

Not only motor skills and perception can move. Emotions are sole and unique in every individual case ( $\mathrm{Vy}$ gotsky, 1982a, p. 94). Equally mobile are processes of recognition and memory with its inevitable reconstructions during reproducing. Experience shows that thought can move too. The postulate of beaten paths (routes) in the nervous system being rigid is well in the past. About 70 years ago Bernstein suggested that neural processes that provide perception and action occur as non-localizable qualitative dynamisms. Neuroscientists use an analogy similar to the web claiming that the dendritic network of a living organism moves as tree branches in a light breeze. As a result we have most precise movements and actions only because of the mobility and excess of degrees of freedom inherent to semantic, motor, perceptual (cognitive, in the broadest sense of the word), affective and nervous systems. Movements and actions being both powerful and the lightest, full of grace, beauty and meaning. Another thing is that so far we still replace our lack of 
understanding of the mechanisms of this miracle with symbols (for example, "soaring, soulful flight"), or with words ("the order out of chaos", "synergy", "resonance", "heterogenesis", etc). But gradually, with each new vibrating web the secret of constructing action is becoming more tangible. And the key role of the "web of the meaning in integrating all the mechanisms of construction and regulation of acts of behaviour and activity is becoming more apparent too. It would be no exaggeration to say that from the beginning the meaning is present in the biodynamic and sensual tissue of living motion and image. After all, meaning is the unknown quantity. It would be more accurate to say that living motion is a meaning in a search for self. That comprises the main difference between the mechanical motion and the living motion. And it creates and defines all other differences (Gordeeva, 1995). But the found meaning in its pure form is elusive. It immediately transforms into an operational, perceptual, and then a verbal meaning, into the meaning of acts of behaviour and activity happening now. It does not disappear in them but is hidden under their cover causing a problem for those who want to understand such acts.

Studying the processes of extracting or making sense is a serious problem for cognitive psychology too. Spinoza once said that memory is an intellecting searching for self. When the microarray analysis of short-term visual memory was performed using an artificial experimental procedure, a functional unit of semantic information processing was found located after the sensory register, iconic memory, the scanning unit... Further studies have shown that with the improvement of the system of infor- mation processing in relation to a particular substantive content, the unit of semantic processing is mysteriously moved into the first place and begins to guide the work of the entire system. The latter transforms from a mnemonic into an intellectual one.

The metaphor of the circulatory system of meaning belongs to G.G. Shpet, in whose works the notion of "meaning" was dominant. He never tired of emphasizing the dynamic aspect of semantic system. G.G. Shpet, like L.S. Vygotsky, associated the word with the mind and thought. The word is likened to the organism (cf. with N.A. Bernstein's metaphor: motion as a living creature), and meaning acquires an organic existence in the word structure. The metaphor of meaing as the filling of the circulatory system may well compete with Max Weber's metaphor discussed above. Both metaphors are very productive and complement each another. If one is allowed to fantasize a little, one can wonder about how the web of objective meanings created by humanity transforms and fills the semantic circulatory system of the spiritual organism of an individual. How does the "external" meaning become an internal meaning or an individual's own meaning? How do both semantic systems communicate, interact and enrich each other? How does the perceptive field become a field of meaning and so on. The circulatory system of meaning can become clogged or sclerotized. The metaphor opens up other possibilities for understanding too.

G.G. Shpet mentions another very important metaphor of meaning as being a dialectical accumulator of 
thoughts. This metaphor is similar to the transcendental drive of Osip Mandelstam that provides a transmission (distribution) of the energy of meaning. Since every thought that is not idle is a thought about meaning, the opposite is also true: the idea is the same accumulator of meanings. It is a small distance between meanings swirling and the nuclei of the semiosphere, of which Lotman later wrote.

The metaphor of the semantic wave belongs to O. Mandelstam. Describing the inner form of the word, G.G. Shpet focuses on the dynamics of logical semantic forms. We shall illustrate this dynamics by describing how the meaning of poetic speech appears. The description was given by Osip Mandelstam who voluntarily or involuntarily was Shpet's associate (!). Both of them had in common not only thoughts, but their fate too. The poet died in a GULAG camp a year after G.G. Shpet was murdered. Describing Dante' instrumental poetry and distinguishing it from the external explanatory imagery, Mandelstam writes: "Semantic waves-signals disappear after performing their work: the stronger they are, the more compliant they are and less inclined to linger... The quality of poetry is dependent on the speed and determination with which it introduces its ideas-orders of performance into the non-instrumental lexical purely quantitative nature of word formation. The meaning of poetic speech is created through running across the entire width of a river cluttered with Chinese junks moving in different directions. The meaning (likewise a route) can not be recovered by asking the boatmen: they will not tell you how and why we were jumping from one junk to another" (Mandelstam, 1987, p. 109). Elsewhere the poet says: Light waves cut through like teeth. Perhaps semantic and light waves are shown by the poet as metaphors of each other. Both of them have generating properties. If so, then meaning performs an instrumental function. It is a mediating means remaining, of course, a meaning, a cothought and (like a symbol) a mystery. Although multiple commentators of great works of art devote voluminous manusripts to the search for semantic waves-signals that underly creative work, and then are embodied and scattered in its findings, any agreement reached between them is extremely rare. Their authors are hardly aware of this:

My words are sad. I do know that. But you will never understand their meaning.

I am tearing them out of my heart So that the torments are torn out with them.

M. Lermontov

In statements by poets there is an idea of the primacy of meaning in arts alongside remarkable descriptions of the elusiveness of meaning, and the likening of it to invisible waves-signals (a kind of reduction of the wave function). As soon as we discuss the physical analogs of meaning, then, along with the waves, we should talk of quanta. This assumption is yet premature. N.D. Gordeeva, indeed, found waves and quanta in the living motion but her data indicates that the carrier of the meaning is a wave, not a quantum. Andrei Bely talked not about quanta, but of droplets of meaning. 
The metaphor of the rainbow of meaning. A. Bely protested against the existence of abstract truth and insisted on its dynamic qualities: "the growth process of meaning has no pauses and is fluid; in it separate meanings are droplets; a rainbow arises from them; it is the meaning. There is either no truth, or truth is a gesture of meanings. The doctrine of the dynamic truth presupposes it as a fluid form, as a form in motion; the idea of a form in motion is a representation of the organism; the organism is a fluid diversity in the indivisible; its elements taken out of it are empty frozen forms" (Bely, 1991, p. 24).Vladimir Nabokov too wrote in his novel The Gift on truth as a flowing form: "The molders of opinion were incapable of understanding Hegel's vital truth: a truth that was not stagnant, like shallow water, but flowed like blood, through the very process of cognition" (Nabokov, 1963). Once again, we are faced with the search for the mysteries of the semantic nature of creativity. It is significant that Bely speaks of the form in motion and of gestures of meanings. Earlier we mentioned the living motion as the meaning searching for itself. The same applies to substantive action, in particular to creating action (V. Kandinsky). In 1924 A. Tufanov when describing the aesthetics of A Real Art Association pointed out how original the representatives' work on meaning was. Their common goal was to broaden and deepen the meaning of the object, word and action. D. Harms was focused on "not a static figure, but on a collision of a number of objects, on their relationship. At the time of action the object takes a new specific shape that is full of real meaning. The action in a new way owns a "classic" pattern but at the same time it represents a broad attitude to the sense of the world" (Tufanov, 1982, p. 558). The same applies to the collision of verbal meanings in poetry, which (in the words of Tufanov) expresses the meaning of the object with the accuracy of mechanics (Ibid., p. 584). In the same year 1924, when his book appeared, the first studies of N.A. Bernstein were published: he was always amazed at the precision of living motion: it is carried out by a kinematic system that has a great number of redundant degrees of freedom.

The same happens with images. S. Eisenstein used the collision of images when making films to produce not only a new, but also an exact meaning. N. Zabolotsky used words for this clash (the same gesture of meanings). Harms almost personified meanings: "Wake me strong to fight with meanings." It is your equal who you could fight with. I. Severyanin also personified the meaning and, without false modesty, felt his superiority over it:

\section{I am the nightingale, and besides the songs, \\ There is no other use of me. I am so meaninglessly wonderful That meaning bowes to me!}

The metaphor of the cloud of meaning belongs to G.P. Schedrovitsky. A cloud of meaning is to be expected since we have had a wave, a droplet, and a rainbow of it. L.S. Vygotsky talks of the cloud of thought, and G.P. Schedrovitsky talks about the cloud of meaning. Vygotsky when describing the inner speech talked about the evaporation of speech into thought. Such evaporation, in his logic, apparently, forms a 
cloud, which then pours as a rain of words. Schedrovitsky was inclined to identify meaning with a field of understanding in the collective mental activity in which meaning is born. Ideal objects of thought stand out in the total "semantic cloud" of understanding and mental work and later they are recorded in the material of sign schemes" (Schedrovitsky, 1995, p. 281). In fact, such a "semantic cloud that comprises different meanings (situational to personal and superpersonal) hovers not only over the mental, but also over all other tasks solved by man. John Updike was "enraptured by Brodsky's gallant attempt to distil a precious meaning from life's experience." The image of distilling is more accurate than the image of evaporation and it also suggests the cloud, or an aura of meaning.

We shall point out that some metaphors of meaning given above correspond well to each other. We can "see them how": a cloud of meaning rises over the abyss of meaning produced by either evaporation, or distilling, that pours in droplets of the meaning. A sudden insight gives rise to the rainbow of meaning that connects edges of the abyss. The world is perceived by the individual through the personal web of meanings spun by him or her. Everything happens as shown in the picture Fuji through the Cobwebs by Hokusai. The artist showed the perception of the sacred mountain using cobwebs whether as a symbol of semantic sphere of the observer, or as a symbol of spiritual aura that enfolds Fujiyama. And perhaps both possible meanings converge in the web.

All this together can be called a collective image of the life of meaning and its various incarnations. This dynamic collective image of meaning is consistent with its fluid, dynamic nature.

The metaphor of the meaning as a plant belongs to A. Bely. Although he formulated it in the context of the meaning of knowledge, it is directly related to the mystery of creation: "The doctrine of the dynamic truth changes our understanding of thought: the meanings of truth are plants; the doctrine of the static truth is similar to the attitude to grain: the grain of truth given as a concept is prematurely consumed by us; if we had planted it, it would have sprouted as a many-grained ear; the grains of the ear would have germinated in a stalk; the stalk would have produced a field; the selfless attitude to the truth multiplies the circle of its life; it is defined not by the grain but throught a plurality of grains. The truth $\mathrm{A}$ is not in the grain but in the rhythm of ripening grains..." (Bely, 1991, p. 24).

C.G. Jung shared the metaphor of a plant as he likened the work in statu nascendi to a living being; to a tree drinking from the soil the fluids needed; to a baby in the womb; to the autonomous complex of soul, etc. At the core of the idea of a work of art there is a primal word, a primal image, or an archetype to which Jung attributes elemental forces. Sometimes he identifies these structures with the suprapersonal meaning, which may transcend the artist and his ability to think and feel. Jung understands the symbol as a possibility of a wider, higher meaning beyond our immediate perceptual ability and as a hint of it (Jung, 1992, pp. 108-120). N.L. Muskhelishvili and Yu.A. Shreyder developed a 
similar hypothesis of the plant image, "the image as an organizer" (in the biological sense) (1998). But unlike A. Bely and Jung, the authors, following Vygotsky, endow these images with a sense but not a meaning.

The metaphor of a path and of $a$ search for a vertical horizon. As to the metaphor of meaning as of a way, its orientation and direction, it is widespread, as they say, "in the words of the people." But to this metaphor should be added the indispensable requirement of M. Bakhtin. The search for the meaning of life can be effective only when my unique place in existence is recognized: "The meaning of existence, for which my only place in the existence is not recognized as essential, will never be able to understand me and that is not the meaning of existence-consciousness" (Bakhtin, 2003b, p. 13).

An amazingly accurate image of searching for a vertical horizon belongs to Brodsky. The poet once uttered that life was a sum of small movements. If the word "life" is replaced with an almost equivalent to it word "meaning", we can say that meaning is a sum of small movements. The movements seeking meaning and the movements fulfilling the found meaning. Movements of the soul are no exception. Living motion is remarkable in that it is characterized not only by moving in space and time but also by enduring, the feeling of own (including generating) activity. Living motion is a creative movement that designs its own space, time and meaning (an active chronotope in the terminology of A.A. Ukh- tomsky and M.M. Bakhtin). Living motion transcends space and time with the found meaning and takes these harsh definitions of existence into possession. Brodsky noticed a remarkable feature of living motion:

while pacing my way along the surface, I use the altimeter of pride...

and this is how his I finds its vertical horizon. The found meaning becomes a vertical dimension of psychological time, and, respectively, of existence. Some called it the fourth dimension, some - the fifth dimension of existence. Although it should be called the first. Again, the act of discovering or finding, or falling into understanding (Mamardashvili) of meaning remains mysterious. So mysterious that T.S. Eliot associates it with "a moment not out of time." But this is a moment of time, "what we call history." These moments create time that is named a personal history or biography: "My soul is but a moment's gleam..." , said Marina Tsvetaeva. "En lui rendant un instant manifeste" (moments becoming revelations) (Rilke).

The metaphor of the face of meaning belongs to M.M. Bakhtin. Like the previous one it is closely linked to the future: "My definition of myself is given to me (or rather, is given as a givenness, a given givenness) not in terms of temporal being, but in terms of not-yet-being, in terms of purpose and meaning, in semantic future that is hostile to any presence of mine in the past and in the present. To be for oneself

\footnotetext{
${ }^{2}$ Translated by Andrey Kneller.
} 
means yet to appear to oneself (to stop appearing in front of self and to come to being everything present means spiritual death)" (Bakhtin, 2003a, p. 194). Bakhtin insists on pushing meaning into the future: "The world of my semantic future is foreign to the world of my past and present < ..> I (in my meaning and in my value for myself) am thrown into the world of the infinitely demanding meaning" (Ibid.). The face of meaning is a meaning that opposes existence and appears in front of him. If the inner existence opposes itself to meaning as a value in itself and becomes self-prevailing and self-sufficient in the face of meaning, this brings existence into a profound contradiction with itself, in self-denial; it becomes a lie: the existence of lies or the lie of existence (Ibid., p. 195).

Without going further into $\mathrm{M}$. Bakhtin's doctrine of meaning we can say that the main message is in the need to develop a dominant of the soul towards the face of meaning. Bakhtin identifies meaning and spirit. And according to A.A. Ukhtomsky, one of the main dominants of the soul is the focus on spirit. Another imperative of Ukhtomsky is the dominant towards the face of another. Combining the views of the two thinkers (Ukhtomsky and Bakhtin), we can say that from the moment both the face of another person and the face of meaning are revealed (and sometimes they are identical), the person for the first time deserves to be talked about as a persona.

$* * *$

We do not seek to exhaust all the metaphors of meaning. It is just as difficult as to exhaust all available interpre- tations of the concept of meaning. And it is not necessary. To exhaust concepts and metaphors of meaning means to murder the latter. For "the spoken word is the mortal flesh of the meaning" (Ibid., p. 202). It is animated by a living metaphor. Therefore a metaphorical aspect is an inherent feature of any verbal thought including scientific thought and not only the poetical one.

Along metaphors mentioned above (soft, vivid, transparent) there are also hard, tough metaphors, for example, the semantic core, the semantic framework, semantic construct, the aforementioned semantic barrier, semantic foundation that deserve a separate discussion. We shall dwell only on one type of the metaphors. It is a metaphor of meaning as a rock that was despised by builders though it should become the cornerstone (L.S. Vygotsky put practice and philosophy as the cornerstone). For Acmeists the conscious meaning of word, the Logos, is as beautiful a form, as music to symbolists (as Mandelstam put it). For him, meaning acted as poetic matter; D.A. Leontiev talks about the semantic tissue (another "soft" metaphor), which he puts on a par with the biodynamic and sensual tissue. Mandelstam spoke about Acmeists: "... We introduce the Gothic into the relationships of words, like Johann Sebastian Bach established it in music." The poet recalls Vladimir Solovyov who cared for the "mute eloquence of granite boulders" and gives his understanding of the known lines by Tyutchev: "But Tiutchev's rock (that "The boulder that rolled down the mountain to lie in the valley, Did it impel itself, or did another cast it?") is the word. In this unexpected fall physical matter's voice sounds like articulate 
speech... Acmeists gratefully raise Tyutchev's mysterious rock and put it into the foundation of their building."

The rock as if yearned for another existence. It discovered an inherent capacity (as if it wanted to become part of a "vaulted arch") of an impetus to participate in a joyful interaction with its own kind" (Mandelstam, 1987, p. 169).
Should psychology follow the example of Acmeists and put the rock - the rock of meaning - into the "vaulted arch" of its building that is perpetually under construction? We hope that the world as the air of disinterested meaning (B. Pasternak) that is revealed in its meaningful images and metaphors will contribute to this work already in progress.

\section{References}

Averintsev, S. S. (1979). Klassicheskaya grecheskaya filosofiya kak yavleniye istoriko-literaturnogo ryada [Classical greek philosophy as a historical and literary phenomenon]. In S. S. Averintsev (Ed.), Novoye v sovremennoy klassicheskoy filosofii [New in modern classical philology]. Moscow: Nauka.

Bakhtin, M. M. (2003a). Avtor i geroi v esteticheskoi deyatelnosti [The author and the hero in aesthetic activity]. In M. M. Bakhtin, Sobranie sochinenii [Collected works] (Vol. 1). Moscow.

Bakhtin, M. M. (2003b). K filosofii postupka [On the philosophy of deed]. In M. M. Bakhtin, Sobranie sochinenii [Collected works] (Vol. 1). Moscow.

Bely, A. (1991). O smysle posnaniya [On the meaning of knowledge]. Minsk: Polifakt.

Gordeeva, N. D. (1995). Eksperimentalnaya psikhologia ispolnitelnogo deistviya [Experimental psychology of executive action]. Moscow: Trivola.

Husserl, E. (1952). Ideas, General introduction to pure phenomenology. London: Allen and Unwin.

Jung, C. G. (1992). Fenomen dukkha v iskusstve i nauke [The phenomenon of spirit in art and science]. Moscow: Renessans.

Leontiev, D. A. (1999). Psikhologiya smysla: priroda, stroyenie $i$ dinamika smyslovoi realnosti [Psychology of meaning: the nature, structure and dynamics of the semantic reality]. Moscow: Smysl.

Lotman, Y. (2005). On the Semiosphere. Sign Systems Studies, 33(1), 205-226.

Mandelstam, O. (1987). Slovo i kultura [Word and culture]. Moscow: Sovetskii pisatel'.

Muskhelishvili, L., \& Schreyder, Yu. A. (1998). Znacheniye teksta kak vnutrenniy obraz [The meaning of the text as an internal image].Voprosy Psikhologii, 3, 79-91

Nabokov, V. (1963). The Gift (1st Vintage International ed.). New York: G. P. Putnam's Sons.

Ricoeur, P. (1990). Zhivaya metafora [Live Metaphor]. In N.D. Arutyunova (Ed.), Teoriya metafory [Theory of metaphor], (pp. 435-455). Moscow: Progress.

Schedrovitsky, G. P. (1995). Izbrannye trudy [Selected works]. Moscow: Izdatel'stvo shkoly kul'turnoi politiki.

Shpet, G. G. (1989). Sochineniya [Works]. Moscow: Pravda.

Shpet, G. G. (2007). Esteticheskiye fragmenty [Aesthetic fragments]. In G. G. Shpet, Izbranniye trudy po filosofii kultury [Selected works on the philosophy of culture] (Vol. 4, pp. 173-286). Moscow: ROSSPEN. 
Shreider, Yu. A. (2000). Smysl [Meaning]. In Novaya filosofskaya entsiklopedia [New encyclopedia of philosophy] (Vol. 3). Moscow: Mysl'.

Stepanov, Yu. S. (2004). Protei. Ocherki khaoticheskoi evolutsii [Proteus. Essays on Chaotic Evolution]. Moscow: Yazyki slavyanskoi kul'tury.

Tufanov, A. (1982). Zaumi. Fonicheskaya musyka i funktsiya soglasnykh fonem [Nonsense. Phonic music and the function of consonants]. In Z. Barański (Ed.), Rosyjskie kerunki literackie przełom 19 i 20 wieki. Warszawa: Państwowe Wydawn. Naukowe. (in Russian)

Vasilyuk, F. E. (1984). Psykhologiya perezhivaniya [Psychology of Experience]. Moscow: Moscow University Press.

Vygotsky, L. S. (1982a). Sobranie sochinenii [Coll. Op.] (Vol. 1). Moscow: Pedagogika.

Vygotsky, L. S. (1982b). Sobranie sochinenii [Coll. Op.] (Vol. 2). Moscow: Pedagogika.

Vygotsky, L. S. (1982c). Sobranie sochinenii [Coll. Op.] (Vol. 5). Moscow: Pedagogika.

Vygotsky, L. S. (1996). Psikhologiya iskusstva [The psychology of art]. Moscow.

Zinchenko, P. I. (1961). Neproizvolnoye zapominaniye [Involuntary memorization]. Moscow: Akademiya pedagogicheskikh nauk RSFSR.

Zinchenko, V. P. (1997). Posokh Osipa Mandelshtama i trubka Mamardashwili. K nachalam organicheskoi psikhologii [Osip Mandelstam' Staff and Mamardashvili's Pipe. On the origins of organic psychology]. Moscow: Novaya shkola.

Zinchenko, V. P. (2002). Psikhologicheskiye osnovy pedagogiki [Psychological foundations of pedagogics]. Moscow: Gardariki.

Zinchenko, V. P. (2006). Geterogenez mysli: podkhody L.S. Vygotskogo i G.G. Shpeta (prodolzhenie razgovora) [The heterogenesis of thought: Approaches of L.S. Vygotsky and G.G. Shpet (Conversation continued)]. In Gustav Shpet $i$ sovremennaya filosofiya gumanitarnogo znanya [Gustav Shpet and modern philosophy of human knowledge] (pp. 82-135). Moscow: Yazyki slavyanskikh kul'tur.

Работа печатается по изданию: Зинченко, В. П. (2012). Живые метафоры смысла. В кн. Т. Г. Щедрина (ред.), Методология психологии: проблемы и перспективы (с. 29-50). СПб.: Центр гуманитарных инициатив.

Перевод и публикация материалов производились с разрешения ЦГИ Принт. 